\title{
Natural Moisturizer Based on Green Grass Jelly (Cyclea Barbata Miers) with Stevia Leaf Addition (Stevia Rebaudiana Bertoni)
}

\author{
Ahmad Thoriq Mubarok ${ }^{*}$, Kun Harismah ${ }^{2}$ \\ ${ }^{1}$ Department of Chemical Engineering, University of Muhammadiyah Surakarta, Road of A. Yani, Mendungan, \\ Pabelan, Kartasura Subdistrict, Sukoharjo Regency, Central Java 57162, Indonesia. \\ ${ }^{2}$ Department of Chemical Engineering, University of Muhammadiyah Surakarta, Road of A. Yani, Mendungan, \\ Pabelan, Kartasura Subdistrict, Sukoharjo Regency, Central Java 57162, Indonesia. \\ * Corresponding author: thoriqscout@gmail.com
}

\section{ARTICLE INFO}

Article history

Received May 2, 2020

Revised May 26, 2020

Accepted May 26, 2020

Available Online May 31, 2020

Keywords

Moisturizers

Green Grass leaves Stevia

\begin{abstract}
Skin moisturizer is a chemical that can protect the skin from the sun. Natural ingredients that can be used as a moisturizer are Green Grass Jelly. Green Grass Jelly leaves contain antioxidants that can prevent skin aging. The purpose of this study was to analyze the application of Green Grass Jelly and Stevia as a facial moisturizing ingredient. The variables used in this study were Green Grass Jelly consentration of $2.5 \%, 5 \%, 7.5 \%$, and $10 \%$. And stevia benefits $0 \%, 5 \%, 7.5 \%, 10 \%$ and $12.5 \%$. the method used is Green Grass Jelly extraction, stevia extraction and moisturizing preparations. The test used were homogeneity analysis, $\mathrm{pH}$ measurement, specific gravity, dispersion, emulsion reliability, and organoleptic. Based on SNI-16-4399-1996 all samples that have been made meet the existing standards and also suitable sample formulations are $\mathrm{F}(\mathrm{D})$ ie $2.5 \%$ Green Grass Jelly composition and $5 \%$ stevia.
\end{abstract}

This is an open access article under the $\mathrm{CC}-\mathrm{BY}$-SA license.

\section{Introduction}

Skin care requires special attention, because the skin is an outermost layer covering almost all surfaces of the human body. One form of skin maintenance is skin moisturizer. Empirically moisturizing is used as a preventive and treatment of surfactants and irritant dermatitis. Some products state that they not only enhance the barrier function by providing moisturizers but also create an optimal environment for healing. However, the clinical efficacy of moisturizing remains a topic of controversy. However, moisturizers may be ineffective widely and may be relatively specific to certain acids, bases, hydrophilic, and lipophilic. We need to develop what principles are formulated in 
moisturizers to improve efficacy; For this purpose, there is a need for experimental moisturizing models for comparative studies.

Dry skin can be solved using moisturizers. Moisturizers can hydrate skin, soften skin and reduce dryness of the skin. Moisturizing components consist of occlusive, humectant, emollient and auxiliary materials[1].

Stevia leaves grow fertile on fertile soil conditions in the form of upper layer soils containing many natural ingredients. For the perfect growth required conditions that fit the acidity between $\mathrm{pH}$ 6 to Neutral ( $\mathrm{pH} \mathrm{7)}$. In this case it is necessary sufficient amount of water because if the amount of excess water will cause damage to the stem stevia[2]. Stevia (Stevia Rebaudiana Bertoni) is a type of plant from the Asteraceae family. Stevia has two glycoside compounds, namely Steviosida 5-10\% and rebaudiosides A 2-4\% that have a corrosion of 110-270 and 140-400 times from sucrose and Stevia is highly contained in terpenoids compounds and flavonoidnya so that it has the effectiveness to be used as antibacterial[3]. Stevia leaves (Stevia rebaudiana) have been used as a sweetener in South America over the centuries-long berabads, and are currently consumed around the world. In fact, it is 300 times sweeter than sucrose, with the added benefit of having: zero calories, zero carbohydrates, and does not cause a surge in blood sugar levels. The sweetness of this plant is due to being treated as shape glycosides: Steviosida (4-13\%), rebaudiosides A (2-4\%), rebaudiosides C (1-2\%), Dulcosida A (0.4-0.7\%), and other less abundant types such as Steviolmonosida, powder, steviolbiocide, rebaudiosides B and Rebaudiosides F[4].

Green Grass Jelly is a medicinal plant that can be consumed in the form of functional food, such as desserts and healthy snacks. Traditionally it is used as a heat-lowering drug, gastric radasng osbat, relieving nausea, to high blood loss. The results showed that grass jelly water extracts could lower the cancer cells. Even extracts from the root grass jelly have activity as an antioxidant. Some of the components that are active role in grass jelly are carotenoids, flavonoids, and chlorophyll[5]. Green Grass Jelly has a function as a natural green dye, a source of rich chlorophyll antioxidants and natural fiber sources. The grass is extracted using water, resulting in a gel. Green Grass Jelly Gel contains a polysaccharide pectin, which is like gelatin. Grass jelly leaf gels contain antioxidants and chlorophyll. Green Grass leaf is able to form a window such as gelatin[6].

The problem formulation of this research is how the effectiveness of natural moisturizers of stevia leaf extract and green grass jelly leaves for skin care.

\section{Methods}

\subsection{Research Methodology}

The research methodology used in this study is to use the complete random design Method 2 factors using 4 treatment variations of green grass jelly formula $(2.5 \% ; 5 \% ; 7.5 \%$; and $10 \%)+$ stevia $(5 \%, 10 \%, 15 \%, 20 \%, 25 \%)$ and 1 treatment of formulations without green grass.

\subsection{Variable Research}

\subsubsection{Independent variable}

The free variables that this research used are:

a. Increase in green grass concentrations: $0 \% 2.5 \%, 5 \%$, and $7.5 \%$

b. Added stevia concentration: $0 \% 2.5 \%, 5 \%, 7.5 \%$, and $10 \%$

\subsubsection{Fixed variable}

The fixed variables used were the temperature with the following values:

a. Extraction temperature grass jelly: $50^{\circ} \mathrm{C}$

b. Stevia extraction temperature: $78^{\circ} \mathrm{C}$

c. Moisturizing manufacturing Temperature: $35^{\circ} \mathrm{C}, 40^{\circ} \mathrm{C}$, and $70{ }^{\circ} \mathrm{C}$

\section{do}




\subsubsection{Dependent Variable}

The dependent variable is the parameter that will be observed when all the test series have been carried out. In this study the parameter to be observed is the level of effectiveness at each concentration of moisturizer.

\subsection{Procedure Research}

\subsubsection{Green Grass Leaf Extraction}

The making of the powder is started by washing the fresh grass with cold water, then dried with oven $50 \mathrm{oC}$ for 18 hours or drying from 08.00 to 15.00 for three days (total 21 hours). Then the dried leaves are milled and sifted with the Sieve 100 mesh. Then take 25 grams of grass jelly that has been sifted as much as 25 grams and given aquades $600 \mathrm{ml}$, inserted in the beaker glasses 1,000 $\mathrm{ml}$ and then heated to a temperature of 90 degrees Celsius for 1 hour. Then filtered and dried until the water in grass is exhausted. Then mashed and sifted on 200 mesh.

\subsubsection{Stevia Leaf Extraction}

Daun stevia yang telah dikeringkan dan dihaluskan sampai ukuran 60 mesh dicampur dengan pelarut etanol perbandingan $1: 5$. Dilakukan pengadukan selama 3 hari, filtrat kemudian dipekatkan dengan menggunakan alat rotary evaporator pada tekanan vakum [3].

\subsubsection{Procedure of Moisturizing}

The materials used are weighed using a digital scale, with the following composition: Glycerin weighed as much as 10 grams, TEA weighed as much as 0.6 grams, and the water weighed as much as 169 grams by using a glass beker $250 \mathrm{ml}$ (water phase or 1 preparation), stearic acid weighed as much as 2.4 gram, monostearic glyceryl PEG-100 stearate weighed as much as 4.8 grams, using the porcelain cup $100 \mathrm{ml}$ (oil phase or 2 preparations). Both preparations are heated to a temperature of $70-75^{\circ} \mathrm{C}$ while stirring periodically, then the oil phase (dosage 2) is inserted into the water phase (1), stirring until homogeneous. Preparations that have been homogeneous mixed and stirred with the stirrer to $40^{\circ} \mathrm{C}$ (dosage 3 ). Preservatives (methyl paraben) and perfume weighed and inserted into the dosage of 3 at $35^{\circ} \mathrm{C}$ Then, is done stirring again for approximately one minute. The samples are weighed against the concentration, then homogenized with a slight dosage to homogeneous, then mixed into the overall dosagefi[7].

\subsection{Analysis Research}

2.4.1 Organoleptic Test

Organoleptical observation can be seen by the separation of phases or rupture of cream, aroma and discoloration.

\subsubsection{Homogenity}

The testing of homogeneity is done by placing a dosage between 2 glass objects and a coarse particulate/unhomogenization is noted.

\subsection{3 pH measurements}

The cream is inserted into the container, then the $\mathrm{pH}$ is measured using a $\mathrm{pH}$ meter indicator and produces a $\mathrm{pH}$ acid

\subsubsection{Coverage}


Cream as much as 0.5 grams over the watch glass coated with graph paper. It was then loaded with the same watch glass for 60 seconds, and was given each load weighing $50 \mathrm{~g}, 100 \mathrm{~g}, 150 \mathrm{~g}$ and $200 \mathrm{~g}$ and left for 60 minutes. The spread diameter is calculated by measuring the average diameter of multiple edges.

\subsubsection{Emulsion Stability}

The measurement of the emulsion material is inserted in the container and weighed as much as 2.5 grams, the container and materials are inserted into the oven with a temperature of $45 \mathrm{oC}$ for 1 hour, then inserted into the cooler temperature below $0 \mathrm{oC}$ for 1 hour and returned again to the oven with a temperature of $45 \mathrm{oC}$ for 1 hour. Then count the water that can not be mixed.

\subsubsection{Density Analysis}

The type weights are measured using a picnometer at $20^{\circ} \mathrm{c}$. Measurement of the type of weight with a pycnometer with a thermometer as follows, weighed thoroughly the empty pycnometers (A), a picnometer containing water (B), and a picnometer containing the dosage $(\mathrm{C})$. The weight of the dosage type is calculated with the following formula:

$$
\mathrm{BJ}=\frac{\mathrm{C}-\mathrm{A}}{\mathrm{B}-\mathrm{A}}
$$

\subsubsection{Flavonoids Test}

The standard solution used is kuersetin with a concentration of $10 \mathrm{ppm}, 20$ ppm, $30 \mathrm{ppm}, 40 \mathrm{ppm}, 50 \mathrm{ppm}$. Determination of flavonoids levels in green grass extract is done by dissolving $2.5 \%, 5 \%, 7.5 \%$ of the extract with the aquadest volume chopped up to $10.0 \mathrm{~mL}$ and homogenized. Next it is $1.0 \mathrm{~mL}$ of the solution into the Erlenmayer $25 \mathrm{~mL}$ for 3 replication. Each solution was added with $0.1 \mathrm{~mL}$ of potassium acetate solution, $0.1 \mathrm{~mL}$ Aluminium chloride solution, $10 \mathrm{ML}$ of aquadest whipped until homogeneous. Pre-made solution is added to the room temperature for 30 minutes. Absorption is measured at a wavelength of $435 \mathrm{~nm}$. Total flavonoids levels are calculated from the default curve of Kuersetin. Total flavonoids content is expressed as the number of MG equivalently kuersetin per gram of extract.

\section{Results and Discussion}

The study used the concentration influence of Stevia extract and green grass leaves in the manufacture of moisturizing formulations. The resulting moisturizers are then physically formulated, including Test homogenity, $\mathrm{pH}$ measuring test, type weight test, scatter power test, and emulsion stability test.

\footnotetext{
dof 


\subsection{Uji Organoleptik}

Based on the results of the tests that have been done to 20 people who tried our products, obtained the following data:

Table 1. Organoleptic observation Result (color)

\begin{tabular}{|c|c|c|c|c|c|}
\hline \multirow[b]{2}{*}{ Numb. } & \multirow[b]{2}{*}{$\begin{array}{l}\text { Variation } \\
\text { treatment }\end{array}$} & \multicolumn{4}{|c|}{ Organoleptic (Color) } \\
\hline & & White & $\begin{array}{l}\text { Light } \\
\text { Green }\end{array}$ & $\begin{array}{c}\text { Concentrated } \\
\text { Green }\end{array}$ & $\begin{array}{c}\text { Dark } \\
\text { Green }\end{array}$ \\
\hline 1. & $\mathrm{~F}(\mathrm{~A})$ & 20 & - & - & - \\
\hline 2. & $\mathrm{~F}(\mathrm{~B})$ & - & 2 & 16 & 2 \\
\hline 3. & $\mathrm{~F}(\mathrm{C})$ & - & 20 & - & - \\
\hline 4. & $\mathrm{~F}(\mathrm{D})$ & - & - & 15 & 5 \\
\hline 5. & $\mathrm{~F}(\mathrm{E})$ & - & - & 3 & 17 \\
\hline 6. & $\mathrm{~F}(\mathrm{~F})$ & - & - & 2 & 18 \\
\hline
\end{tabular}

Table 2. Organoleptic observation Result (texture)

\begin{tabular}{|c|c|c|c|c|c|}
\hline \multirow{2}{*}{ Numb. } & \multirow{2}{*}{$\begin{array}{c}\text { Variation } \\
\text { treatment }\end{array}$} & \multicolumn{5}{|c|}{ Organoleptic (Tekxture) } \\
\cline { 3 - 6 } & & Very Dilute & Dilute & Thick & Very Thick \\
\hline 1. & $\mathrm{~F}(\mathrm{~A})$ & 1 & 3 & 16 & - \\
\hline 2. & $\mathrm{~F}(\mathrm{~B})$ & - & 3 & 11 & 6 \\
\hline 3. & $\mathrm{~F}(\mathrm{C})$ & 8 & 11 & 1 & - \\
\hline 4. & $\mathrm{~F}(\mathrm{D})$ & - & 6 & 13 & 1 \\
\hline 5. & $\mathrm{~F}(\mathrm{E})$ & - & 3 & 13 & 4 \\
\hline 6. & $\mathrm{~F}(\mathrm{~F})$ & - & 3 & 5 & 12 \\
\hline
\end{tabular}

Table 3. Observation Results of Organoleptic Scents

\begin{tabular}{|c|c|c|c|c|c|}
\hline \multirow{2}{*}{ Numb. } & \multirow{2}{*}{$\begin{array}{l}\text { Variation } \\
\text { treatment }\end{array}$} & \multicolumn{5}{|c|}{ Organoleptic (Aroma) } \\
\cline { 3 - 6 } & & Perfume & $\begin{array}{c}\text { Perfume } \\
\text { and Stevia }\end{array}$ & $\begin{array}{c}\text { Perfume and } \\
\text { Green Grass } \\
\text { leaf }\end{array}$ & $\begin{array}{c}\text { Perfume and } \\
\text { distinctive } \\
\text { both }\end{array}$ \\
\hline 1. & $\mathrm{~F}(\mathrm{~A})$ & 19 & - & 1 & - \\
\hline 2. & $\mathrm{~F}(\mathrm{~B})$ & - & 1 & 19 & - \\
\hline 3. & $\mathrm{~F}(\mathrm{C})$ & 4 & 15 & 1 & - \\
\hline 4. & $\mathrm{~F}(\mathrm{D})$ & - & 6 & 4 & 10 \\
\hline 5. & $\mathrm{~F}(\mathrm{E})$ & - & 2 & 4 & 14 \\
\hline 6. & $\mathrm{~F}(\mathrm{~F})$ & - & 1 & 1 & 18 \\
\hline
\end{tabular}

The Data is late from organoleptic test of color, aroma, and texture. The F (A) sample can be concluded that with a non-sampled moisturizer acquired has a perfume scent, with a thick texture and white color. Sample F (B) can be concluded that with a moisturizer with grass jelly $2.5 \%$ and stevia $0 \%$ obtained has a scent of perfume and grass grass jelly, with a thick texture and dark green color. Sample F (C) can be concluded that with a moisturizer with grass jelly $0 \%$ and stevia $2.5 \%$ obtained has a stevia scent, with a dilute texture and light green color. Sample F (D) can be concluded that with a moisturizer with grass jelly $2.5 \%$ and stevia $5 \%$ obtained has a distinctive aroma of grass jelly and stevia, with a thick texture and dark green color. Sample F (E) can be concluded that with a moisturizer with grass jelly $5 \%$ and stevia 7.5\% obtained has a distinctive aroma of grass jelly and stevia, with a thick texture and 
deep green color. F (f) samples can be concluded that with a moisturizer with grass jelly $7.5 \%$ and a stevia $10 \%$ obtained has a distinctive aroma of grass jelly and stevia, with a very thick texture and deep green color.

\subsection{Homogenity}

The results of the research have been done to observe the formulation of the moisturizing ingredients of each sample by placing the sample on the Petri dish that is pinned and observed the sample. Then the data obtained from $\mathrm{F}(\mathrm{A})$ to $\mathrm{F}(\mathrm{F})$ are all homogeneous. This shows that there is no change from the addition of grass jelly or stevia so that all variations are homogeneous or evenly mixed.

\section{$3.3 \mathrm{pH}$ acidity degree test}

Based on the results of the tests obtained the following data:

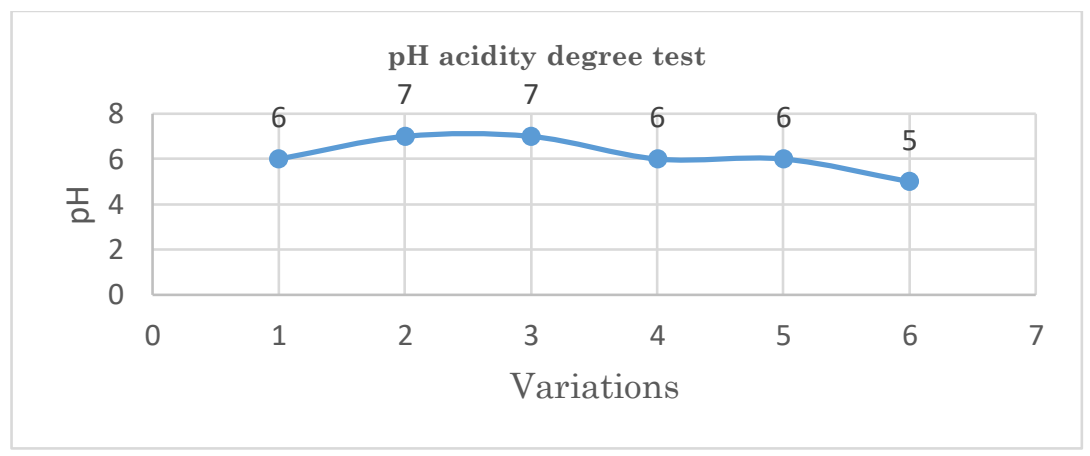

Figure 1. Chart of $\mathrm{pH}$ acidity degree test

Based on the $\mathrm{pH}$ value of all the formulas meet the $\mathrm{pH}$ requirement of skin moisturizing dosage $4.5-8$ (SNI-16-4399-1996). Lotion that has a $\mathrm{pH}$ too alkaline can cause the skin to become dry, whereas if the $\mathrm{pH}$ is too acidic will cause irritation. The results of the moisturizing $\mathrm{pH}$ test showed that the $\mathrm{pH}$ was getting down from $\mathrm{pH} 7$ to $\mathrm{pH} 5$, from the observation result of $\mathrm{F}(\mathrm{B})$ to $\mathrm{F}(\mathrm{F})$, the $\mathrm{pH}$ occurred due to the addition of stevia. It is the same as described by[3]. that the Stevia $\mathrm{pH}$ range ranges from 5-6, resulting in more concentrations of stevia extracts. 


\subsection{Spesific Grafity Test}

Specific grafity testing for each sample obtained the following data:

\begin{tabular}{|c|c|c|}
\hline Numb & Variations & Spesific Grafity \\
\hline 1. & F(A) & 0,977 \\
\hline 2. & F(B) & 0,976 \\
\hline 3. & F(C) & 0,886 \\
\hline 4. & F(D) & 1,02 \\
\hline 5. & F(E) & 1,03 \\
\hline 6. & F(F) & 1,00 \\
\hline
\end{tabular}

Table 4. Spesific Grafity Result Test

Table 4 shows that stevia which is not variated with grass jelly green affects the quality of skin moisturizers due to the value of the type weight (BJ) skin moisturizer that corresponds to the standard SNI 16-4399-1996 which is 0.95-1.05 g/ml. In the formulation of F (C) to $F(f)$ there is an increase in the rate of 2017 study But the formulation of $F(C)$ is $2.5 \%$ stevia and $0 \%$ grass jelly Hijau does not conform to SNI standards because of the possibility of the concentration of stevia less high or stevia has not been added with grass jelly.

\subsection{Test Coverage}

In the coverage test, each sample obtained the following data:

Table 5. Scatter Power Test Results

\begin{tabular}{|c|l|c|c|c|c|c|}
\hline \multirow{2}{*}{ Numb. } & \multirow{2}{*}{$\begin{array}{c}\text { Variation of } \\
\text { treatment }\end{array}$} & \multicolumn{5}{|c|}{ Diameter(mm) } \\
\cline { 3 - 7 } & & 0 & $50 \mathrm{~g}$ & $\begin{array}{c}100 \\
\mathrm{~g}\end{array}$ & $\begin{array}{c}150 \\
\mathrm{~g}\end{array}$ & $\begin{array}{c}200 \\
\mathrm{~g}\end{array}$ \\
\hline 1. & $\mathrm{~F}(\mathrm{~A})$ & 49 & 52 & 52,5 & 53 & 54 \\
\hline 2. & $\mathrm{~F}(\mathrm{~B})$ & 47,5 & 53,5 & 58,5 & 61 & 63 \\
\hline 3. & $\mathrm{~F}(\mathrm{C})$ & 70 & 74 & 75 & 75,5 & 76 \\
\hline 4. & $\mathrm{~F}(\mathrm{D})$ & 34 & 34,5 & 35 & 35,5 & 36 \\
\hline 5. & $\mathrm{~F}(\mathrm{E})$ & 41 & 44 & 45,5 & 48,5 & 50 \\
\hline 6. & $\mathrm{~F}(\mathrm{~F})$ & 39 & 45 & 47 & 47,5 & 48 \\
\hline
\end{tabular}

From the late data tested shows that the greatest coverage is on the $\mathrm{F}(\mathrm{C})$ Formulation of stevia $2.5 \%$ and grass jelly $0 \%$, as well as the least minor coverage is $\mathrm{F}(\mathrm{D})$ which is stevia $5 \%$ and grass jelly $2.5 \%$. The addition of stevia and grass jelly concentrations on moisturizers makes the coverage even larger. Because of the difference in coverage, because the factors due to the viscosity of each of the dosage formula, the greater the viscosity, then the cream prisoner to spread also the wider and the the power of the bar becomes smaller. The good coverage test is $3-5 \mathrm{~cm}$. 


\subsection{Emulsion type stability test}

The spread of tests on each sample obtained the following data:

Observations were made against the possibility of separation of water from emulsions. When the separation occurs, the emulsion is said to be unstable and its stability level is calculated based on the integral phase percentage of the overall emulsion. The level of stability of the sample is more stable when the concentration increases grass jelly and stevia.

\subsection{Flavanoid Test}

Flavonoids are potentially natural compounds as antioxidants that can ward off free radicals that play a role in the onset of degenerative diseases through a mechanism of destruction of the body's immune system, lipid oxidation and protein. Determine the total level of flavonoids from grass jelly green by comparing the standard solution to the comparison of Kuersetin. In the measurement of total flavonoids compounds, sample solution added $\mathrm{AlCl} 3$ that can form complex, so that there is a shifting wavelength in the direction visible (visible) which is characterized by a solution resulting in a more yellow color. And the addition of

Table 6. Emulsion Stability Test Result

\begin{tabular}{|l|l|l|}
\hline 1. & $\mathrm{~F}(\mathrm{~A})$ & $30,2 \%$ \\
\hline 2. & $\mathrm{~F}(\mathrm{~B})$ & $36,24 \%$ \\
\hline 3. & $\mathrm{~F}(\mathrm{C})$ & $67,52 \%$ \\
\hline 4. & $\mathrm{~F}(\mathrm{D})$ & $69,52 \%$ \\
\hline 5. & $\mathrm{~F}(\mathrm{E})$ & $77,88 \%$ \\
\hline 6. & $\mathrm{~F}(\mathrm{~F})$ & $78,88 \%$ \\
\hline
\end{tabular}

potassium acetate that aims to maintain the wavelength of the visible area[8]. Here are the data obtained from the research:

Table 7. Emulsion Stability Test Result

\begin{tabular}{|c|c|c|}
\hline No & Concentration $(\mathrm{ppm})$ & Absorbance $\left(\mathrm{A}^{\circ}\right)$ \\
\hline 1 & 10 & 0,087 \\
\hline 2 & 20 & 0,1383 \\
\hline 3 & 30 & 0,2036 \\
\hline 4 & 40 & 0,4006 \\
\hline 5 & 50 & 0,407 \\
\hline
\end{tabular}

From the data above is data from the solution Kuersetin for as a comparison solution, and obtained graphs and equations to calculate the absorption as follows: 


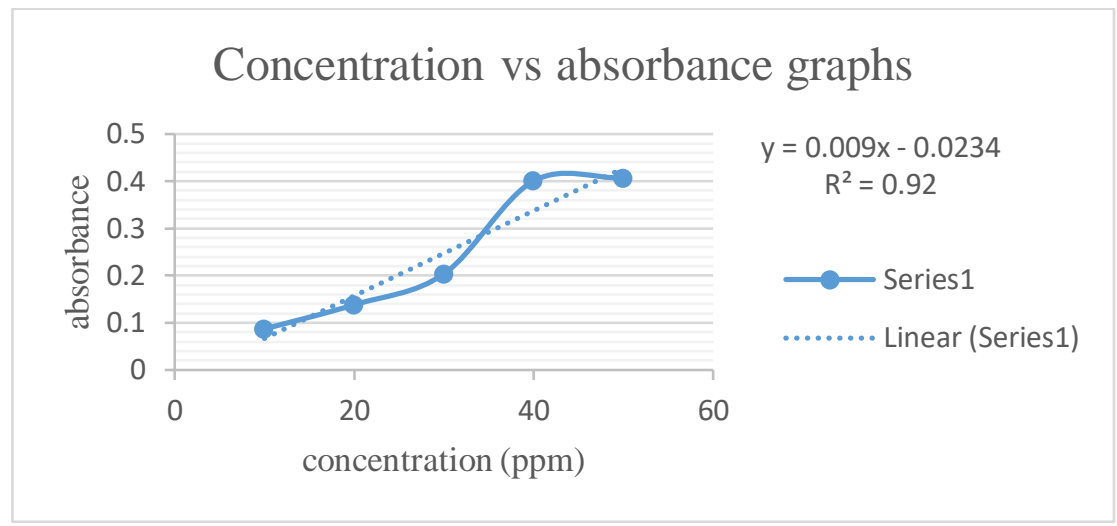

Picture 2. Kuersetin absorbance Chart Results

From the above graph can be known equation, namely $\mathrm{y}=0,009 \mathrm{x}-0.0234$ and Coefficiencies correlation (R2) $=0.92$ to know the strong, moderate, or weak relationship between the variables studied. Then look for the data absorbance from a sample of grass jelly green and obtained the following data:

Table 8. Green Grass absorbancy result Data

\begin{tabular}{|c|c|c|}
\hline Numb. & Concentrarion (\%) & Absorbance $\left(\mathrm{A}^{\circ}\right)$ \\
\hline 1 & 2,5 & 0,32 \\
\hline 2 & 5 & 0,55 \\
\hline 3 & 7,5 & 0,64 \\
\hline
\end{tabular}

Once the data is obtained from grass jelly green, it is inserted into the equation $\mathrm{y}=0$, $009 \mathrm{x}-0.0234$ as the $\mathrm{Y}$ value and obtained flavonoids levels as follows:

Table 9. Data of the results of flavanoid content

\begin{tabular}{|c|c|c|}
\hline Numb & Absorbance $\left(\mathrm{A}^{\circ}\right)$ & Flavanoid levels (ppm) \\
\hline 1 & 0,32 & 38,15556 \\
\hline 2 & 0,55 & 63,71111 \\
\hline 3 & 0,64 & 73,71111 \\
\hline
\end{tabular}

From the data it is obtained at a concentration of grass jelly $2.5 \%, 5 \%$ and $7.5 \%$ obtained flavonoids levels of 38.15556, 63.71111, and $73.71111 \mathrm{ppm}$.

\section{Conclusion}

Based on the results of a natural moisturizing green leaf-based moisturizer study (Cyclea barbata Miers) with the addition of Stevia leaf (Stevia rebaudiana Bertoni) can be concluded that:

1. The resulting moisturizer based on the most preferred organoleptic test is the formulation of $\mathrm{F}$ (D) which is moisturizing with grass jelly 2, $5 \%$ and Stevia $5 \%$ obtained by the scent of grass and Stevia leaves, with thick texture and dark green color.

2. The moisturiser is tested for its homogenization, obtained by the results that secrete a homogeneous mixed formulation. 
3. A moisturiser tested the Tarung acidity of its $\mathrm{pH}$, based on the SNI-16-4399-1996 a good moisturizer has a $\mathrm{pH}$ of $4,5-8$. Produce samples that are tested according to the existing SNI. 4. It is a type of moisturizing weight tested, based on SNI-16-4399-1996, a good moisturizer has a weight of $0,95-1,05 \mathrm{~g} / \mathrm{ml}$. Remove the sample that is tested according to the existing SNI.

5. It is a type of moisturizing weight tested, based on SNI-16-4399-1996, a good moisturizer has a weight of $0,95-1,05 \mathrm{~g} / \mathrm{ml}$. Remove the sample that is tested according to the existing SNI.

6. It is a moisturizer that has been tested the power of the bar, a good moisturizer has a coverage of $3-5 \mathrm{~cm}$. From the late data that has been tested the greatest coverage is on the formulation F (C) namely Stevia 2, 5\% and grass jelly $0 \%$, and the most small coverage is $\mathrm{F}(\mathrm{D})$ is stevia $5 \%$ and grass Jelly 2,5

7. Moisturizers that are tested for its emulation stability, obtained by the result that more and more concentrations of grass jelly green and stevia are added, the greater the stability of the emulating.

\section{References}

[1] E. H. Sinulingga, A. Budiastuti, and A. Widodo, "Efektivitas Madu Dalam Formulasi Pelembap Pada Kulit Kering," J. Kedokt. Diponegoro, vol. 7, no. 1, pp. 146-157, 2018.

[2] K. Harismah, M. Mirzaei, and A. M. Fuadi, " Stevia rebaudiana in Food and Beverage Applications and Its Potential Antioxidant and Antidiabetic: Mini Review ," Adv. Sci. Lett., vol. 24, no. 12, pp. 9133-9137, 2018, doi: 10.1166/asl.2018.12110.

[3] A. S. Manikam, W. S. Pertiwi, A. Hidayanto, and K. Harismah, "Potensi Ekstrak Daun Stevia ( Stevia Rebaudiana Bertoni ) pada Formulasi Obat Kumur Terhadap Aktivitas Antibakteri Streptococcus Mutans," pp. 27-34, 2017.

[4] A. Periche, M. L. Castelló, A. Heredia, and I. Escriche, "Influence of drying method on steviol glycosides and antioxidants in Stevia rebaudiana leaves," Food Chem., vol. 172, pp. 1-6, 2015, doi: 10.1016/j.foodchem.2014.09.029.

[5] A. Kariza, "Ekstraksi Pektin dari Cincau Hijau (Premna oblongifolia. Merr) Untuk Pembuatan Gel Pengharum Ruangan,” EKSTRAKSI PEKTIN DARI CINCAU HIJAU (Premna oblongifolia. Merr), 2015.

[6] H. T. Palupi, S. Pengajar, P. Itp, F. P. Universitas, and Y. Pasuruan, "PENGARUH KONSENTRASI EKSTRAK DAUN CINCAU HIJAU (Cycle barbata L. Miers) DAN SUHU EKSTRAKSI TERHADAP KARAKTERISTIK MIE BASAH,” J. Teknol. Pangan, vol. 6, no. 1, 2015.

[7] H. E. Fitriani and A. Syawaalz, "PELEMBAB KULIT,” no. 1996, 2004.

[8] A. Aminah, N. Tomayahu, and Z. Abidin, "PENETAPAN KADAR FLAVONOID TOTAL EKSTRAK ETANOL KULIT BUAH ALPUKAT (Persea americana Mill.) DENGAN METODE SPEKTROFOTOMETRI UV-VIS,” J. Fitofarmaka Indones., vol. 4, no. 2, pp. 226-230, 2017, doi: 10.33096/jffi.v4i2.265. 